\title{
49. A PB, SR, AND ND ISOTOPIC STUDY OF BASALTIC ROCKS FROM THE SEA OF JAPAN, LEGS 127/128
}

\author{
Brian L. Cousens ${ }^{2}$ and James F. Allan ${ }^{3}$
}

\begin{abstract}
The western Pacific includes many volcanic island arc and backarc complexes, yet multi-isotopic studies of them are rare. Basement rocks of the Sea of Japan backarc basin were encountered at Sites 794, 795, and 797, and consisted of basaltic sills and lava flows. These rocks exhibit a broad range in isotopic composition, broader than that seen in any other western Pacific arc or backarc system: ${ }^{87} \mathrm{Sr} /{ }^{86} \mathrm{Sr}=0.70369$ to $0.70499,{ }^{143} \mathrm{Nd} /{ }^{144} \mathrm{Nd}=0.51267$ to $0.51317,{ }^{206} \mathrm{~Pb} /{ }^{204} \mathrm{~Pb}=17.64$ to 18.36 . The samples form highly correlated arrays between very depleted mid-ocean ridge basalt (MORB) and the Pacific pelagic sediment fields on $\mathrm{Pb}-\mathrm{Pb}$ plots. Similarly, on plots of $\mathrm{Sr}-\mathrm{Pb}$ and $\mathrm{Nd}-\mathrm{Pb}$, the $\mathrm{Sea}$ of Japan samples lie on mixing curves between depleted mantle and enriched mantle ("EM II"), which is interpreted to be of average crustal or pelagic sediment composition. The source of these backarc rocks appears to be a MORB-like mantle source, contaminated by pelagic sediments. Unlike the Mariana and Izu arc/backarc systems, Japanese arc and backarc rocks are indistinguishable from each other in a Sr-Nd isotope plot, and have similar trends in $\mathrm{Pb}-\mathrm{Pb}$ plots. Thus, sediment contamination of the mantle wedge appears to control the isotopic compositions of both the arc and backarc magmas. Two-component mixing calculations suggest that the percentage of sediments in the magma source varies from $0.5 \%$ to $2.5 \%$.
\end{abstract}

\section{INTRODUCTION}

A controversial problem in the understanding of the dynamics of arc systems has been the source and origin of backarc volcanism. The radiogenic isotope geochemistry of volcanic arc and backarc lavas is an important tool in discriminating processes that may occur in subduction zones. Such processes include dewatering of the subducting slab and subsequent metasomatism of the overlying mantle wedge, recycling of pelagic sediments into the mantle, partial melting of the slab as it undergoes metamorphism, partial melting of variably depleted mantle peridotite, and crustal assimilation (e.g., Arculus and Powell, 1986; Ellam and Hawkesworth, 1988). Correlations between $\mathrm{Sr}, \mathrm{Nd}$, and $\mathrm{Pb}$ isotopic systems have allowed geochemists to identify different chemical "components" in the mantle (e.g.,Zindler and Hart, 1986), which may include altered ancient oceanic crust, pelagic sediments, continental crust and lithosphere, and "depleted" mantle (the source of MORB).

The western Pacific includes many volcanic island arc and backarc complexes, yet comprehensive isotopic studies of them are rare. In this paper, we present the results of a high-precision isotopic study of backarc basaltic rocks from the Sea of Japan, drilled during Ocean Drilling Program (ODP) Legs 127 and 128 (Fig. 1), and examine the implications of these rocks for the composition of the mantle beneath the Sea of Japan. The goals of Legs 127/128 in the Sea of Japan were (1) to determine the age and nature of the basement, (2) measure the direction and magnitude of the present stress field, and (3) to characterize the sedimentation, subsidence, and oceanographic evolution of the area. Our goal is to use coupled trace element and isotopic studies to determine the components that are present in the mantle beneath the Sea of Japan and to infer the nature of subduction processes acting in this area.

\footnotetext{
${ }^{1}$ Tamaki, K., Suyehiro, K., Allan, J., McWilliams, M., et al., 1992. Proc. ODP, Sci. Results, 127/128, Pt. 2: College Station, TX (Ocean Drilling Program).

${ }^{2}$ Ocean Drilling Program Canada, Département de Géologie, Université de Montréal, CP. 6128, Succursale A, Montréal (Québec), H3C 3J7, Canada.

${ }^{3}$ Ocean Drilling Program, Texas A\&M University, 1000 Discovery Drive, College Station, TX 77845, U.S.A.
}

\section{PREVIOUS WORK}

Isotopic data from western Pacific island arc and back-arc basalts are sparse compared to those available for mid-ocean ridge basalts (MORB) or ocean island basalts. Much of the previous work has been on rocks from the Mariana arc (Meijer, 1976; Stern and Ito, 1983; Hole et al., 1984; Woodhead and Fraser, 1985; Hawkins and Melchior, 1985; Woodhead et al., 1987), but some samples from the Tonga-Kermadec arc (Oversby and Ewart, 1972; Ewart and Hawkesworth, 1987), the Philippine Sea (Meijer, 1973), the Philippine Island arc (Defant et al., 1989), the Japanese volcanic arc (Tatsumoto, 1969; Nohda and Wasserburg, 1981; Notsu, 1983; Nohda and Wasserburg, 1986; Tatsumi et al., 1988; Nohda et al., 1988), eastern China (Zhou and Armstrong, 1982; Peng et al., 1986) and the Sea of Japan (Kaneoka et al., 1990) have been analyzed. Isotopic and trace-element differences between island arc lavas and MORB have been interpreted in terms of two models, one in which most western Pacific arc lavas have a depleted, MORB-like source that has been contaminated by subduction of Pacific pelagic sediments, and the other in which MORB-like primary magmas have been contaminated by continental crust/lithosphere. Sediment contamination of the mantle source is best documented in the Sunda arc (Whitford and Jezek, 1979) and has also been proposed for the Mariana and Izu/Bonin arcs, where there is no continental crust exposed in the arc (Meijer, 1976; White and Patchett, 1984; Hole et al., 1984; Woodhead et al., 1987). Trace-element and isotopic data suggest that the percentage of the sediment component in the arc source is between $0.5 \%$ and $1 \%$. Their ${ }^{87} \mathrm{Sr} /{ }^{86} \mathrm{Sr}$ ratios are higher than MORB $(0.7034-0.7038)$, and Mariana lavas are displaced above the Northern Hemisphere reference line (NHRL) toward a field of pelagic sediments in a ${ }^{207} \mathrm{~Pb} /{ }^{04} \mathrm{~Pb}$ vs. ${ }^{206} \mathrm{~Pb} /{ }^{204} \mathrm{~Pb}$ plot. In a ${ }^{207} \mathrm{~Pb} /{ }^{204} \mathrm{~Pb}$ vs. ${ }^{206} \mathrm{~Pb} /{ }^{204} \mathrm{~Pb}$ diagram, rocks from the northwestern, active Tonga arc form a near-vertical array (Oversby and Ewart, 1972; Ewart and Hawkesworth, 1987), much like Japanese arc rocks. Basaltic rocks drilled in the Philippine Sea (DSDP Sites 290-296) have similar ${ }^{87} \mathrm{Sr} /{ }^{86} \mathrm{Sr}$ ratios, and plot above the NHRL in $\mathrm{Pb}-\mathrm{Pb}$ isotope plots. Arc lavas from both northeastern and central Japan form linear trends on $\mathrm{Pb}-\mathrm{Pb}$ plots from moderately depleted MORB toward the sediment field. ${ }^{87} \mathrm{Sr} /{ }^{86} \mathrm{Sr}$ ratios range from 0.7032 to $>0.7055$, and in northeastern Japan ${ }^{87} \mathrm{Sr} /{ }^{86} \mathrm{Sr}$ ratios decrease from the arc front to the backarc region. 


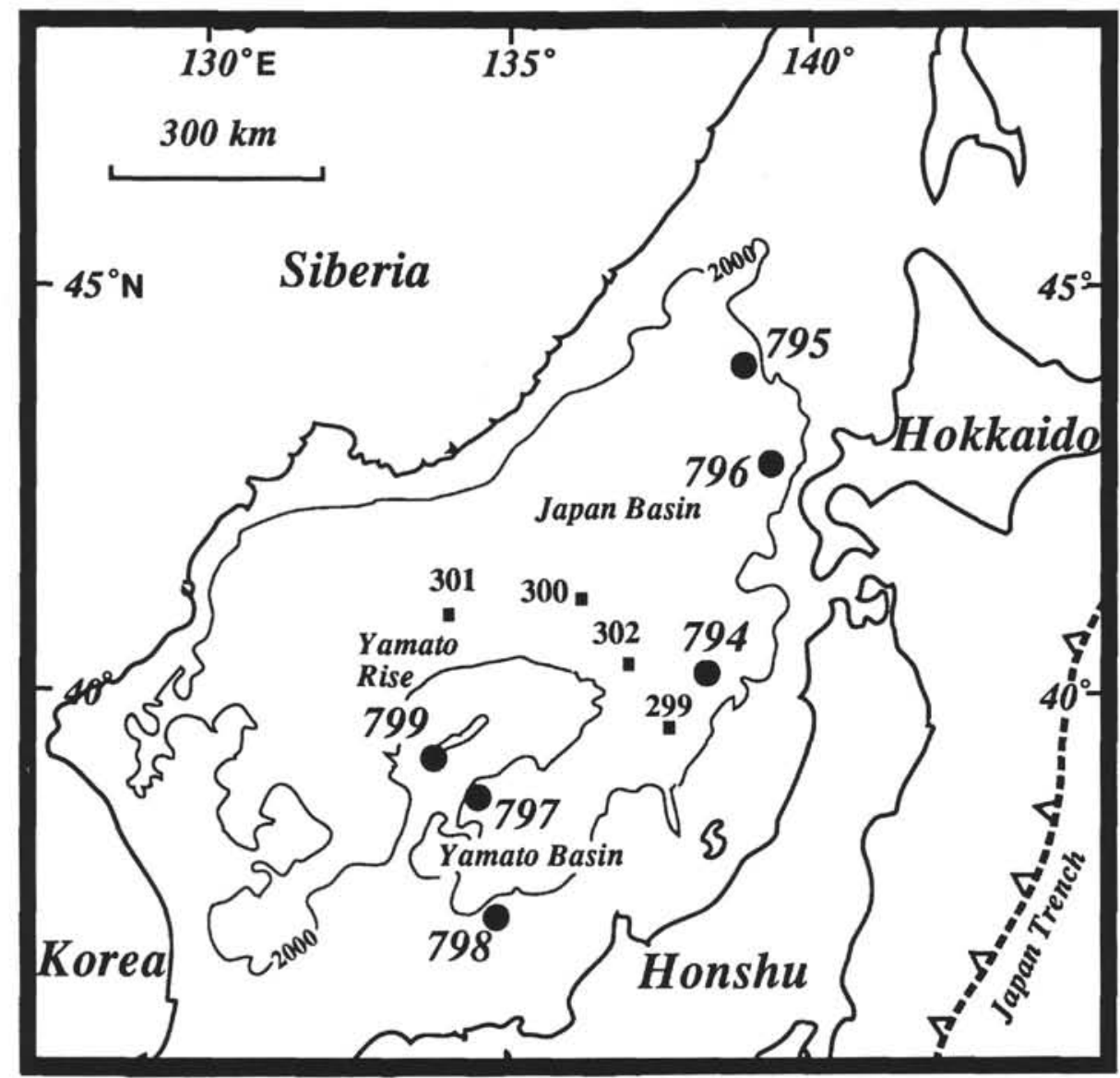

Figure 1. Map of the Sea of Japan showing the locations of Leg 127 drill sites and DSDP Sites 299 to 302. Site 794 was revisited during Leg 128. Bathymetry is in meters.

\section{RESULTS OF ISOTOPIC ANALYSES OF LEG 127 BASALTS}

\section{Analytical Methods}

Basement rocks were encountered at Sites 794, 795, and 797. Samples for isotopic analysis were taken from unit cores adjacent to samples analyzed for major-element, trace-element, and petrographic analysis (Tamaki, Pisciotto, Allan, et al., 1990; Ingle, Suyehiro, von Breymann, et al., 1990; Allan and Gorton, this volume). Basement rocks in Hole 794C were interpreted to be tholeiitic sills intruded into soft, water-rich sediments, as were lower units cored in Hole 794D (Tamaki, Pisciotto, Allan, et al., 1990; Ingle, Suyehiro, von Breymann, et al., 1990). The sampled rocks ranged from fine-grained, aphyric basalt to relatively coarse-grained aphyric to plagioclase phyric dolerite. Units 1 to 5 are mildly LREE enriched, while Units 6 to 9 are less enriched (Allan and Gorton, this volume). Most rock units at Site 797 were also interpreted to be tholeiitic sills or dikes intruded into soft, water-rich sediments (Tamaki, Pisciotto, Allan, et al., 1990). Unit 2 at this Site is a lava flow. Units 1 to 9 (upper complex) have significantly lower concentrations of incompatible major and trace elements than Units 10-21 (lower complex; Tamaki, Pisciotto, Allan, et al., 1990; Allan and Gorton, this volume). Samples analyzed for isotopes from this site consisted of fine to medium grain basalt from both compositional groups. In contrast, samples from Site 795 were taken from massive to brecciated lava flows of calcalkaline basalt to basaltic andesite composition.

All sampled igneous rocks from Legs $127 / 128$ were altered by hydrothermal and diagenetic processes, with alteration often being quite severe especially along the sill margins. Twelve samples from the interiors of the freshest units were chosen for $\mathrm{Sr}, \mathrm{Nd}$, and $\mathrm{Pb}$ isotopic analysis on a Finnigan MAT 261 multicollector mass spectrometer at the University of California, Santa Barbara. Concentrations of $\mathrm{Rb}, \mathrm{Sr}, \mathrm{Sm}, \mathrm{Nd}, \mathrm{U}, \mathrm{Th}$, and $\mathrm{Pb}$ were determined by isotope dilution mass spectrometry. Analytical procedures are those of Cousens et al. (1990). ${ }^{87} \mathrm{Sr} /{ }^{86} \mathrm{Sr}$ ratios were normalized to ${ }^{86} \mathrm{Sr} /{ }^{88} \mathrm{Sr}=0.1194$. The average value obtained for NBS 987 was $0.71022 \pm 1$, and all samples were further normalized to NBS $987=0.71025$. So normalized, four analyses of the $\mathrm{E \& A} \mathrm{SrCO}_{3}$ yielded an average value of $0.70802 \pm 2 .{ }^{143} \mathrm{Nd} /{ }^{144} \mathrm{Nd}$ were normalized to ${ }^{146} \mathrm{Nd} /{ }^{144} \mathrm{Nd}=0.7219$. The average ${ }^{143} \mathrm{Nd} /{ }^{144} \mathrm{Nd}$ ratio measured for the La Jolla standard was $0.51189 \pm 2$, and five runs of BCR-1 yielded an average of $0.51263 \pm 2$. A mass fractionation factor of $0.08 \% / \mathrm{amu}$ was applied to $\mathrm{Pb}$ ratios using NBS 981 as a standard (Todt et al., 1984).

Because samples analyzed for isotopes contained between $10 \%$ and $60 \%$ secondary minerals (mixed-layer clays, sulfides, carbonate), all samples were acid-leached for $24 \mathrm{hr}$ in $6 \mathrm{~N} \mathrm{HCl}$ at $120^{\circ} \mathrm{C}$ to remove alteration products containing seawater $\mathrm{Sr} .{ }^{87} \mathrm{Sr} /{ }^{86} \mathrm{Sr}$ ratios were significantly lower in leached splits than in unleached splits (Table 1). The $\mathrm{Nd}$ and $\mathrm{Pb}$ isotopic compositions of leached and unleached splits were identical, indicating that the leaching process had no effect on $\mathrm{Nd}$ or $\mathrm{Pb}$ isotope ratios. ${ }^{87} \mathrm{Sr} /{ }^{86} \mathrm{Sr}$ ratios correlate well with ${ }^{143} \mathrm{Nd} /{ }^{144} \mathrm{Nd}$ and $\mathrm{Pb}$ isotopic ratios, suggesting that the acid leaching was successful in removing most of the alteration. $\mathrm{Sr}, \mathrm{Nd}$, and $\mathrm{Pb}$ initial ratios were calculated from $\mathrm{Rb} / \mathrm{Sr}, \mathrm{Sm} / \mathrm{Nd}, \mathrm{U} / \mathrm{Pb}$, and $\mathrm{Th} / \mathrm{Pb}$ ratios determined on leached sample splits, assuming basement ages of 16,15 , and $19 \mathrm{Ma}$ for Sites 794, 795, and 797, respectively, as derived from paleontological data (Tamaki, Pisciotto, Allan, et al., 1990). All 
Table 1. Isotopic and trace-element compositions, Leg 127/128 basalts, measured on leached powder splits.

\begin{tabular}{|c|c|c|c|c|c|c|c|c|c|c|c|c|}
\hline $\begin{array}{c}\text { Hole } \\
\text { Core-sect. } \\
\text { Interval }(\mathrm{cm})\end{array}$ & $\begin{array}{l}794 \mathrm{C} \\
2 \mathrm{R}-1 \\
35-38\end{array}$ & $\begin{array}{c}794 \mathrm{C} \\
7 \mathrm{R}-1 \\
24-27\end{array}$ & $\begin{array}{l}794 \mathrm{C} \\
12 \mathrm{R}-4 \\
84-89\end{array}$ & $\begin{array}{l}794 \mathrm{D} \\
11 \mathrm{R}-1 \\
86-88\end{array}$ & $\begin{array}{l}794 \mathrm{D} \\
13 \mathrm{R}-1 \\
83-85\end{array}$ & $\begin{array}{c}795 \mathrm{~B} \\
39 \mathrm{R}-1 \\
5-9\end{array}$ & $\begin{array}{c}795 \mathrm{~B} \\
40 \mathrm{R}-2 \\
\mid 16-121\end{array}$ & $\begin{array}{l}797 C \\
10 R-1 \\
89-91\end{array}$ & $\begin{array}{l}797 \mathrm{C} \\
12 \mathrm{R}-2 \\
72-74\end{array}$ & $\begin{array}{l}797 \mathrm{C} \\
29 R-1 \\
50-53\end{array}$ & $\begin{array}{l}797 \mathrm{C} \\
31 \mathrm{R}-2 \\
30-33\end{array}$ & $\begin{array}{l}797 C \\
45 R-1 \\
81-86\end{array}$ \\
\hline Unit & 2 & 3 & 5 & 6 & 7 & $3 \mathrm{~A}$ & 3B & 2 & 3 & 12 & 13 & 21 \\
\hline $\mathrm{Pb}$ & 0.58 & 1.37 & 1.14 & 0.74 & 0.70 & 0.63 & 0.77 & 0.34 & 0.26 & 2.90 & 1.97 & 2.75 \\
\hline $\mathrm{U}$ & 0.25 & 0.40 & 0.23 & & & & & & & 0.64 & 0.20 & 0.27 \\
\hline Th & 0.43 & 0.57 & 0.57 & & & & & & & 1.35 & 0.31 & 0.77 \\
\hline${ }^{2008} \mathrm{~Pb} /{ }^{204} \mathrm{~Pb}$ & 38.007 & 38.351 & 38.160 & 37.994 & 38.242 & 38.201 & 38.213 & 37.535 & 37.360 & 38.331 & 38.289 & 38.055 \\
\hline${ }^{207} \mathrm{~Pb} /{ }^{204} \mathrm{~Pb}$ & 15.506 & 15.549 & 15.517 & 15.493 & 15.534 & 15.511 & 15.516 & 15.419 & 15.398 & 15.551 & 15.543 & 15.503 \\
\hline${ }^{206} \mathrm{~Pb} /{ }^{204} \mathrm{~Pb}$ & 18.000 & 18.288 & 18.145 & 18.026 & 18.247 & 18.200 & 18.180 & 17.793 & 17.645 & 18.358 & 18.318 & 18.136 \\
\hline $\mathbf{R b}$ & 5.1 & & 4.0 & 0.1 & & 2,9 & 5.7 & & 0.1 & 10.8 & 3.5 & 7.7 \\
\hline $\mathrm{Sr}$ & 299.4 & 218.2 & 273.4 & 310.4 & 221.4 & 187.0 & 147.9 & 183.9 & 165.7 & 210.0 & 229.4 & 228.5 \\
\hline $\begin{array}{l}{ }^{87} \mathrm{Sr} / /^{86} \mathrm{Sr} \\
\text { (unleached) }\end{array}$ & 0.70420 & 0.70483 & $\begin{array}{c}0.70453 \\
(0.70532)\end{array}$ & 0.70491 & 0.70436 & 0.70424 & 0.70420 & 0.70378 & $\begin{array}{c}0.70369 \\
(0.70377)\end{array}$ & 0.70499 & 0.70483 & 0.70455 \\
\hline $\mathrm{Nd}$ & 0.98 & 0.92 & 1.02 & 0.99 & 3.78 & 0.72 & 1.68 & 1.37 & 3.23 & 2.53 & 4.01 & 6.24 \\
\hline Sm & 0.29 & 0.23 & 0.43 & 0.36 & 1.54 & 0.27 & 0.53 & 0.49 & 1.27 & 0.79 & 1.42 & 2.13 \\
\hline${ }^{143} \mathrm{Nd} /{ }^{144} \mathrm{Nd}$ & 0.51288 & 0.51267 & 0.51276 & 0.51274 & 0.51288 & 0.51286 & 0.51286 & 0.51317 & 0.51307 & 0.51278 & 0.51278 & 0.51287 \\
\hline $\mathrm{La} / \mathrm{Sm}_{\mathrm{n}}$ & 1.70 & 1.61 & 1.68 & 1.19 & 0.81 & 1.42 & 1.54 & 0.78 & 0.69 & 1.68 & 1.46 & 1.14 \\
\hline
\end{tabular}

Note: All trace-element concentrations in weight parts per million, with an uncertainty of $\pm 1 \%$. Uncertainties: $\mathrm{Sr}$ and $\mathrm{Nd} \pm 0.00002,{ }^{208} \mathrm{~Pb} /{ }^{204} \mathrm{~Pb} \pm 0.030,{ }^{206} \mathrm{~Pb} /{ }^{204} \mathrm{~Pb}$ and ${ }^{207} \mathrm{~Pb} /{ }^{204} \mathrm{~Pb} \pm 0.020$. Chondrite-normalized La/Sm ratios are from Allan and Gorton (this volume).

isotope ratios discussed in the text are calculated initial ratios based on analyses of leached samples.

\section{Isotopic Compositions}

The basaltic rocks exhibit a broad range in isotopic composition, broader than that seen in any other northwestern Pacific arc or backarc system: ${ }^{87} \mathrm{Sr} /{ }^{86} \mathrm{Sr}=0.70369-0.70499,{ }^{143} \mathrm{Nd} /{ }^{144} \mathrm{Nd}=0.51267$ $-0.51317,{ }^{206} \mathrm{~Pb} /{ }^{204} \mathrm{~Pb}=17.64-18.36,{ }^{207} \mathrm{~Pb} /{ }^{204} \mathrm{~Pb}=15.42-15.55$, and ${ }^{208} \mathrm{~Pb} /{ }^{204} \mathrm{~Pb}=37.36-38.35$.

On plots of ${ }^{208} \mathrm{~Pb} /{ }^{204} \mathrm{~Pb}$ vs. ${ }^{206} \mathrm{~Pb} /{ }^{204} \mathrm{~Pb}$ and ${ }^{207} \mathrm{~Pb} /{ }^{204} \mathrm{~Pb}$ vs. ${ }^{206} \mathrm{~Pb} /{ }^{204} \mathrm{~Pb}$, the samples define highly linear arrays between very depleted MORB and the field of Pacific pelagic sediments (Fig. 2). Samples from both the upper depleted $(\mathrm{La} / \mathrm{Smn}<1)$ complex and the lower enriched $(\mathrm{La} / \mathrm{Smn}$ > 1) complex at Site 797 fall on the regression line, although these complexes have different trace-element patterns (Allan and Gorton, this volume). The basalts from Hole 794 plot slightly above the best-fit line through Site 797 lavas, but also define an array with the same slope as the Site 797 array. Leg 127/128 basaltic rocks are displaced to higher ${ }^{207} \mathrm{~Pb} /{ }^{204} \mathrm{~Pb}$ and ${ }^{208} \mathrm{~Pb} / 204 \mathrm{~Pb}$ ratios at a given ${ }^{206} \mathrm{~Pb} /{ }^{204} \mathrm{~Pb}$ ratio than basaltic lavas from the Mariana or Izu arc/backarc systems. The range in $\mathrm{Pb}$ isotope ratios seen in Leg 127/128 basalts is similar to that seen in basaltic and andesitic lavas from central Japan and northeastern Japan, except that the arc lavas have more variable ${ }^{207} \mathrm{~Pb} /{ }^{204} \mathrm{~Pb}$ and ${ }^{208} \mathrm{~Pb} / 204 \mathrm{~Pb}$ ratios. Like basalts from the Mariana Trough, Sea of Japan lavas cross the NHRL at lower ${ }^{207} \mathrm{~Pb} /{ }^{204} \mathrm{~Pb}$ and ${ }^{206} \mathrm{~Pb} /{ }^{204} \mathrm{~Pb}$ than Pacific MORB. Thus the source of some of these backarc lavas is highly depleted in $\mathrm{U}$ with respect to $\mathrm{Pb}$, more so than the source of modern Pacific MORB.

Basaltic rocks from Sites 797 and 794 fall within the mantle fan on a Sr-Nd isotope plot (Fig. 3). The samples plot just above Miocene to Quaternary Japanese-arc lavas analyzed by Nohda and Wasserburg $(1981,1986)$ as well as Miocene Setouchi volcanics (Ishizaka and Carlson, 1983) and Miocene acidic rocks from the Outer Zone (Terakado et al., 1988) of southwestern Japan. The slightly higher ${ }^{87} \mathrm{Sr} /{ }^{86} \mathrm{Sr}$ at a given ${ }^{143} \mathrm{Nd} /{ }^{144} \mathrm{Nd}$ of some Leg $127 / 128$ basalts, compared to Japanese-arc rocks, may be due to incomplete removal of secondary minerals containing seawater $\mathrm{Sr}$ during the acid leaching procedure. In this plot, arc and backarc rocks from Japan cover the same range of isotope ratios along the mantle array, and are thus indistinguishable. These overlapping $\mathrm{Sr}$ and $\mathrm{Nd}$ isotopic compositions are unusual for western Pacific arc/backarc systems. Basalts from the Mariana Trough are more MORB-like in isotopic composition compared to Mariana arc lavas, and range in composition from depleted Pacific MORB toward the Mariana arc central Island Province in $\mathrm{Pb}-\mathrm{Pb}$ and $\mathrm{Nd}-\mathrm{Sr}$ plots (Volpe et al., 1990; Stern et al., 1990). Basaltic to rhyolitic lavas from the Sumisu backarc rift have the same small range of ${ }^{143} \mathrm{Nd} /{ }^{144} \mathrm{Nd}$ ratios as Izu-arc rocks, but are displaced to lower ${ }^{87} \mathrm{Sr} /{ }^{86} \mathrm{Sr}$ ratios in a Sr-Nd plot (Hochstaeder et al., 1990). Basaltic rocks from other western Pacific and Indonesian arcs generally have much lower ${ }^{143} \mathrm{Nd} /{ }^{144} \mathrm{Nd}$ at a given ${ }^{87} \mathrm{Sr} /{ }^{86} \mathrm{Sr}$ ratio, and plot below the mantle array (Defant et al., 1989).

In plots of ${ }^{87} \mathrm{Sr} /{ }^{86} \mathrm{Sr}$ vs. ${ }^{206} \mathrm{~Pb} /{ }^{204} \mathrm{~Pb}$ and ${ }^{143} \mathrm{Nd} /{ }^{144} \mathrm{Nd}$ vs. ${ }^{206} \mathrm{~Pb} /{ }^{204} \mathrm{~Pb}$ (Fig. 4), the Sea of Japan samples have higher ${ }^{87} \mathrm{Sr} /{ }^{86} \mathrm{Sr}$ and lower ${ }^{143} \mathrm{Nd} /{ }^{144} \mathrm{Nd}$ ratios than Pacific MORB and both the Mariana and Izu arc/back-arc rocks. As noted in other plots, the data points from Leg $127 / 128$ basalts form an array trending from a highly depleted mantle composition toward the field of Pacific pelagic sediments.

Lavas from Site 797 exhibit a correlation between isotope ratios and trace- element composition (Table 1; Fig. 5). In Figures 2 through 5 , it is apparent that basalts from both the upper depleted and lower enriched complexes form correlated arrays, suggesting that lavas from the two complexes are related. Neither fractional crystallization nor variable partial melting of a homogeneous source can be the cause of this correlation. Basalts from Site 794 do not show as good a correlation between isotope ratios and $\mathrm{La} / \mathrm{Sm}_{\mathrm{n}}$ (normalized to chondritic abundances). This implies that the petrogenetic relationships between the basaltic sills drilled at Site 794 are more complex than at Site 797.

\section{DISCUSSION}

The data from Leg 127 and 128 samples indicate that Sea of Japan backarc basalts are isotopically similar to Japanese island-arc lavas, but are different from both MORB and most backarc basalts from the northwestern Pacific. Basalts from the Mariana Trough and Sumisu Rift backarc basins are interpreted to be derived from a predominantly DM source that has been variably contaminated with an enriched "arc component" (Volpe et al., 1990; Stern et al., 1990; Hochstaeder et al., 1990). Similarly, Leg $127 / 128$ basalts appear to have a highly depleted, MORB-like mantle source (DM), and either the source itself or primary melts from the source have been contaminated by "enriched" material (EM). This EM contaminant could be subducted pelagic sediment, slab-derived fluids, subcontinental lithosphere, continental crust, or a combination of any of these materials. 


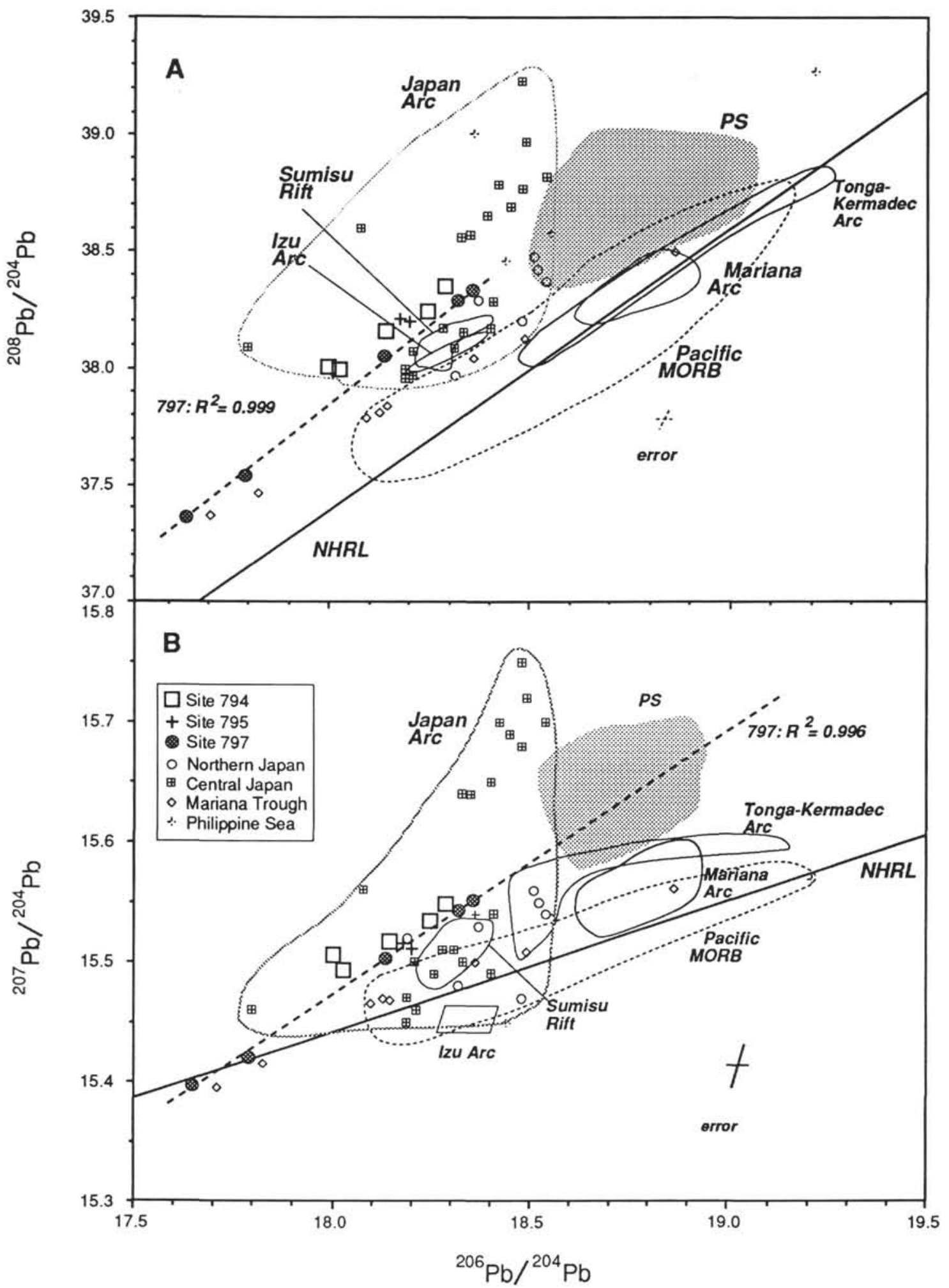

Figure 2. Pb-Pb plots of arc volcanic rocks from (A) the Japan, Mariana, and Tonga arcs, backarc basalts from the Philippine Sea, Mariana Trough, and Sumisu Rift; and (B) Leg 127 basalts from the Sea of Japan. On both plots, $\mathrm{Pb}$ ratios in samples from Site 797 are highly correlated, lying on a line with a steeper slope than the NHRL (Hart, 1984). The best-fit lines (dashed) shown are for Site 797 basalts only. The lines trend from a depleted MORB-like composition toward Pacific pelagic sediments. Most Pacific arc and backarc basalts also plot above the NHRL, displaced toward the sediment field. (Data sources: Tatsumoto, 1969; Meijer, 1973, 1976; Oversby and Ewart, 1972; Nakamura et al., 1985; Ewart and Hawkesworth, 1987; Othman et al., 1989; Stern et al., 1990; Volpe et al., 1990; Hochstaeder et al., 1990.) 


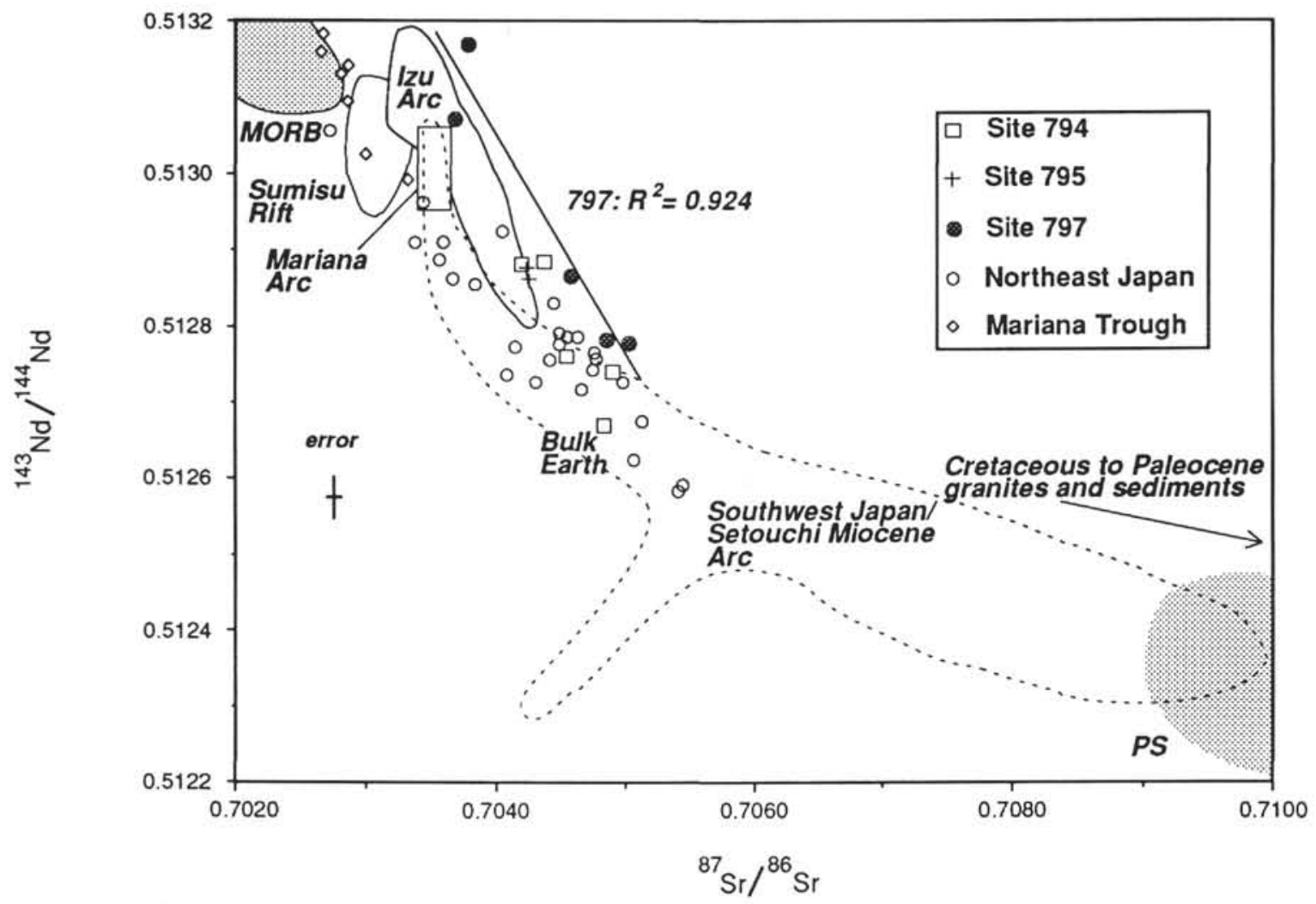

Figure 3. Nd-Sr isotope variation diagram, comparing Leg 127 basalts to volcanic rocks from the Izu, Mariana and Japan arcs, and their back-arc basins. Best-fit correlation line is for Site 797 samples only. (Data sources: Nohda and Wasserberg, 1981, 1986; Ishizaka and Carlson, 1983; Terakado et al., 1988; Morris and Kagami, 1989; Othman et al., 1989; Stern et al., 1990; Volpe et al., 1990; Hochstaeder et al., 1990.)

\section{Slab-derived Fluids}

$\mathrm{H}_{2} \mathrm{O}$-rich fluids driven from the subducting slab are a potential source of large ion lithophile (LIL) elements to the overlying mantle wedge (e.g. Perfit et al., 1980; Gill, 1981; Davidson, 1987). Because seawater Sr is incorporated into altered oceanic crust, slab-derived fluids should have ${ }^{87} \mathrm{Sr} /{ }^{86} \mathrm{Sr}$ ratios greater than typical MORB. However, seawater has a very low $\mathrm{Nd}$ concentration, and thus seawater does not affect ${ }^{143} \mathrm{Nd} /{ }^{144} \mathrm{Nd}$ in altered oceanic crust except under very high water/rock ratios (Eggler, 1987; Ludden and Thompson, 1979). Experimental data (e.g., Tatsumi et al., 1986) suggest that slab-derived fluids have low $\mathrm{Nd} / \mathrm{Sr}$ ratios, so the contribution of these fluids to the Nd concentration and isotopic composition of the mantle wedge is very small (Ellam and Hawkesworth, 1988). The relatively high ${ }^{87} \mathrm{Sr} /{ }^{86} \mathrm{Sr}$ values measured in Leg $127 / 128$ basalts at a given ${ }^{143} \mathrm{Nd} /{ }^{144} \mathrm{Nd}$ ratio (Fig. 3) may reflect either post-emplacement alteration (incomplete removal of seawater Sr by acid-leaching) or excess slab-derived $\mathrm{Sr}$ in the mantle wedge. Leg 127/128 basalts, and western Pacific arc and backarc lavas in general, have both higher ${ }^{87} \mathrm{Sr} /{ }^{86} \mathrm{Sr}$ and lower ${ }^{143} \mathrm{Nd} /{ }^{144} \mathrm{Nd}$ ratios than depleted MORB, suggesting that slab-derived fluids cannot be the sole "enriched" material in the source.

\section{Crustal Contamination}

Previous studies of Japanese-arc volcanics found that there are systematic changes in $\mathrm{Sr}$ and $\mathrm{Nd}$ isotope ratios in Quaternary volcanic rocks in transects both across and along the arc (Notsu, 1983; Nohda and Wasserburg, 1981, 1986). ${ }^{87} \mathrm{Sr} /{ }^{86} \mathrm{Sr}$ ratios decrease, and ${ }^{143} \mathrm{Nd} /{ }^{144} \mathrm{Nd}$ ratios increase, from the arc front to the backarc side of the arc in northeastern Japan (Fig. 5). Quantitative modeling of contamination of an "original magma" (an Izu-arc tholeiitic basalt) by a Cretaceous granite or pre-Silurian gneiss suggests that $10 \%-20 \%$ of the $\mathrm{Sr}$ and
Nd in the Quaternary arc lavas is from the contaminant (Nohda and Wasserburg, 1981). It was also found that there is a secular decrease in ${ }^{87} \mathrm{Sr} /{ }^{86} \mathrm{Sr}$ and increase in ${ }^{143} \mathrm{Nd} /{ }^{144} \mathrm{Nd}$ over the last $27 \mathrm{Ma}$ in volcanic rocks from northeastern Japan (Nohda and Wasserburg, 1986). These results were interpreted to reflect a high level of crustal contamination prior to and during the initial opening of the backarc. Subsequently, the degree of contamination dropped as the continental crust was thinned during the opening of the Sea of Japan. Quaternary arc magmas suffer more contamination at the arc front, where the continental crust is thickest, and become progressively less contaminated to the west where the continental crust is thinner (Nohda and Wasserburg, 1981). This model predicts that Sea of Japan basalts should be relatively uncontaminated, and thus MORB-like isotopically. Yet, they are nearly indistinguishable from Japan arc lavas (see also Kaneoka et al., 1990).

The isotopic data from Leg $127 / 128$ rocks could be interpreted to reflect variable degrees of crustal contamination of basaltic magmas. The crust beneath the Yamato Basin is anomalously thick for purely oceanic crust (12-16 km; Tamaki, 1988; K. Suyehiro, pers. comm., 1990). The seismic velocities of the middle crustal section are consistent with either a thick sill-sediment complex, such as that drilled in Holes 794 and 797, or continental crust that has been thinned and intruded by basaltic magmas. Also, rafts of continental material are found in the Sea of Japan, including the large Yamato Block. Granites of the Yamato Block appear to be approximately $60 \mathrm{Ma}$ in age, and reported ${ }^{87} \mathrm{Sr} /{ }^{86} \mathrm{Sr}$ ratios range from $0.7046-0.7067$ (Ueno et al., 1974). However, the $\mathrm{Mg}$ numbers of Sea of Japan basalts recovered during Legs 127 and 128 are between 0.58 and 0.70 , indicating that they have probably not interacted to an appreciable extent with silicic crust. Interaction between mantle-derived magmas and silicic crust by assimilation/fractional crystallization in small magma chambers, 


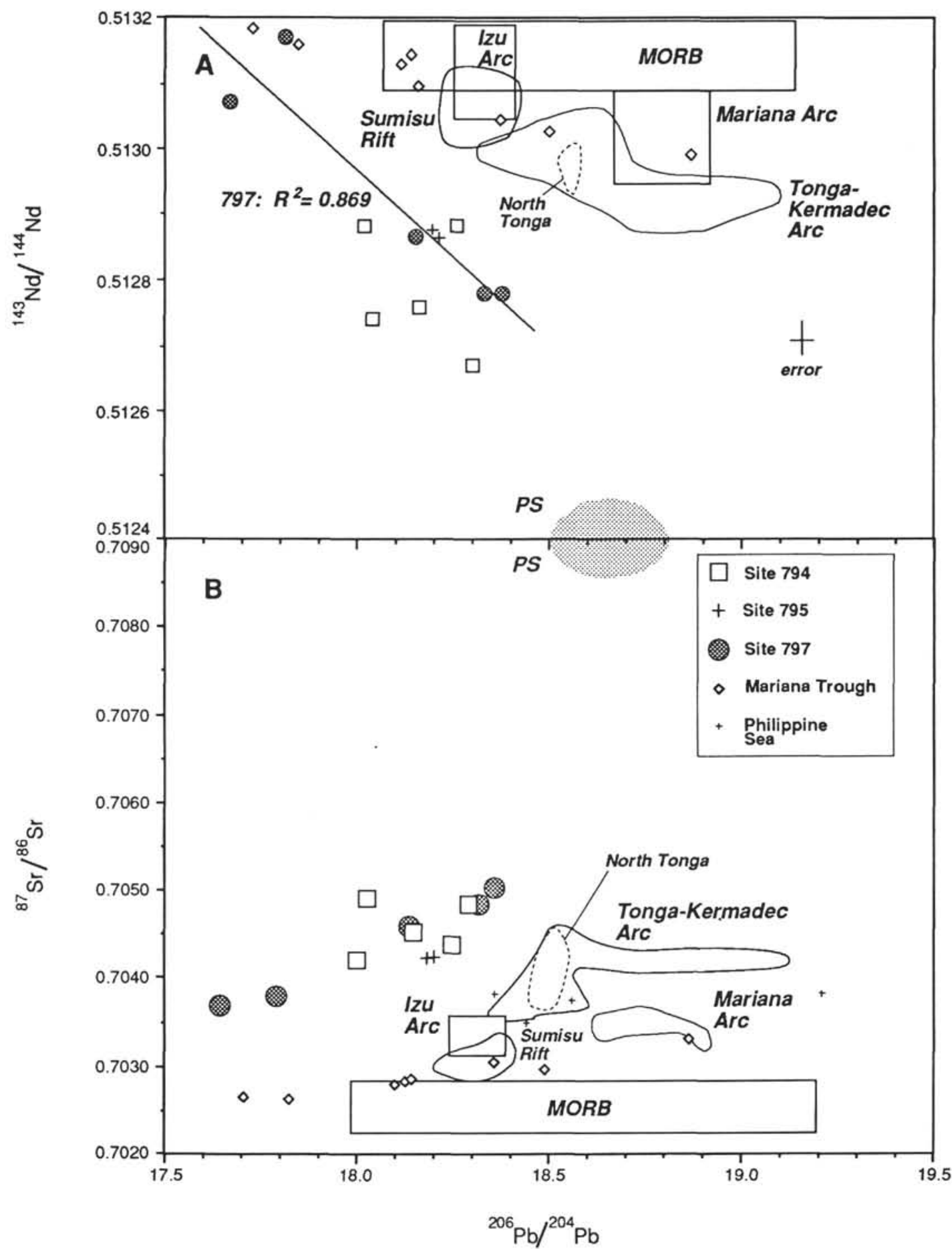

Figure 4. Covariations of ${ }^{206} \mathrm{~Pb} /{ }^{04} \mathrm{~Pb}$ with (A) ${ }^{143} \mathrm{Nd} / 144 \mathrm{Nd}$ and (B) ${ }^{87} \mathrm{Sr} /{ }^{86} \mathrm{Sr}$ in basalts from Leg 127/128; the Philippine Sea; the Mariana arc, the Izu arc, the Tonga arc, and their backarc basins. Note the trend from MORB-like depleted mantle toward Pacific pelagic sediments. Best-fit line is for Site 797 basalts only. Data sources as in Figures 2 and 3.

conduits, or soft sediments, would likely produce a larger scatter on $\mathrm{Pb}-\mathrm{Pb}$ plots, because of the variable composition of continental crust. The isotopic compositions of Leg 127/128 lavas are also inconsistent with the intuitively reasonable continental contamination model of Nohda and Wasserburg (1986) outlined above. For these reasons, we prefer a model whereby the enriched component is located in the mantle source.

\section{Lithospheric Contamination}

A recent reappraisal of the chemistry of Tertiary to Quaternary arc lavas from northeast Japan has concluded that their isotopic and trace-element characteristics are best explained by contamination of primary magmas with subcontinental lithosphere, rather than with continental crust (Tatsumi et al., 1988; Nohda et al., 1988). This 


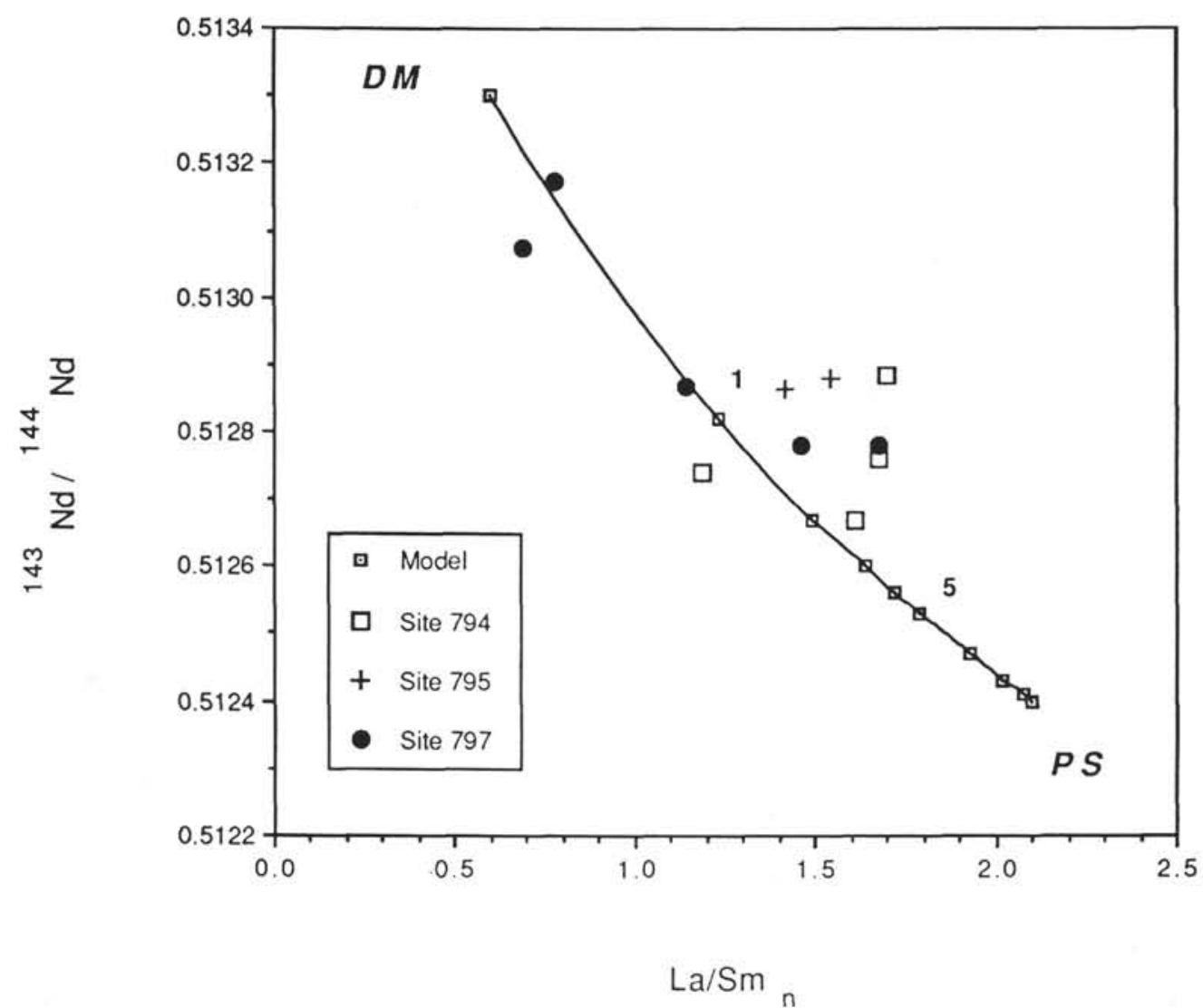

Figure 5. ${ }^{143} \mathrm{Nd} /{ }^{144} \mathrm{Nd}$ vs. $\mathrm{La} / \mathrm{Sm}_{\mathrm{n}}$ for Leg $127 / 128$ basalts. $\mathrm{La} / \mathrm{Sm}_{\mathrm{n}}$ (normalized to chondrites) is from Allan and Gorton (this volume). A two-component mixing curve is shown using the end members listed in Table 2 . DM $=$ depleted MORB source, PS $=$ composite Pacific pelagic sediment. Squares on the curve are shown at $0 \%, 1 \%$ (marked by a "1"), $2 \%, 3 \%, 4 \%, 5 \%$ (marked by a " 5 "), 10\%, 20\%, 60\%, and 100\% PS in the mix. Leg $127 / 128$ basalts contain up to $2.5 \%$ PS component.

modification to the Nohda and Wasserburg (1986) model is largely a result of geophysical data that indicate that the continental crust beneath northeast Japan is not thinner than that beneath the volcanic arc (Tatsumi et al., 1988). Nohda et al. (1988) propose that the opening of the Sea of Japan was the result of asthenospheric injection of depleted mantle beneath the backarc region. Subsequent thinning of subcontinental lithosphere during and after opening of the Sea of Japan would result in lesser degrees of contamination of subsequent primary arc magmas going from the arc front to the backarc region, just as thinning of the continental crust would do. This model, like the Nohda and Wasserburg model discussed in the previous section, predicts that Sea of Japan lavas should be isotopically MORB-like, which is not the case.

The composition of subcontinental lithosphere can be extremely variable (e.g., Menzies, 1989), and as noted by Kaneoka (1990), Nohda et al. (1988) do not present any data that shed light on the composition of the subcontinental lithosphere in the Japan region. Prior to opening of the Sea of Japan, Japan was attached to eastern China, and it is reasonable to assume that Japan and eastern China shared a common subcontinental lithosphere. Clues as to the composition of the subcontinental lithosphere beneath Japan may therefore be found in isotopic data from Neogene to Cenozoic volcanic rocks in eastern China (Zhou and Armstrong, 1982; Peng et al., 1986; Zhi et al., 1990; Song et al., 1990). Unlike northeastern Japan, there is no secular variation in ${ }^{87} \mathrm{Sr} /{ }^{86} \mathrm{Sr}$ in volcanic rocks from easternmost China. From combined incompatible element and isotopic data, Zhou and Armstrong (1982) concluded that tholeiitic volcanic rocks from eastern China are partial melts of subcontinental lithosphere, while alkalic rocks are partial melts from a deeper source which have been recently enriched in incompatible elements. Peng et al. (1986) determined that there was an east to west isotopic transition from arc-like volcanics to lavas with evidence of a late Archean subcontinental lithosphere component: ${ }^{87} \mathrm{Sr} /{ }^{86} \mathrm{Sr}$ ratios increase and ${ }^{143} \mathrm{Nd} /{ }^{144} \mathrm{Nd}$ ratios decrease with decreasing ${ }^{206} \mathrm{~Pb} /{ }^{204} \mathrm{~Pb}$, typical of lavas that are interpreted to have interacted with subcontinental lithosphere (EM I component of Zindler and Hart, 1986; Menzies, 1989; Hawkesworth et al., 1990). The Hannuoba basalts (west of Beijing and west of the Tan-lu Fault) show the same range and trends in isotopic composition as other Cenozoic basalts west of the Tan-lu Fault, providing further evidence that an EM I component is present beneath eastern China (Zhi et al., 1990; Song et al., 1990). Song et al. (1990) conclude that the EM I component could be either mixed in the convecting mantle or trapped within the subcontinental lithosphere.

$\mathrm{Sr}$ and Nd isotopic data for Japan arc and Cenozoic eastern China lavas are compared in Figure 6. Note that for arc rocks from northeastern Japan, it is difficult to determine what the enriched component is, EM I, EM II, or some other component intermediate between the two, because the data all fall within the mantle fan and do not curve appreciably toward any enriched end member. Miocene arc rocks from Japan clearly curve toward EM II, while the China basalts appear to be displaced toward EM I at the end of the mantle fan. In a plot of $\mathrm{Pb}-\mathrm{Pb}$, lavas from eastern China plot above the NHRL and trend toward EM I (Fig. 7A). This trend from MORB to EM I is clearer on plots of $\mathrm{Sr}-\mathrm{Pb}$ or $\mathrm{Nd}-\mathrm{Pb}$ (Fig. 7B). Thus the trends interpreted to be 


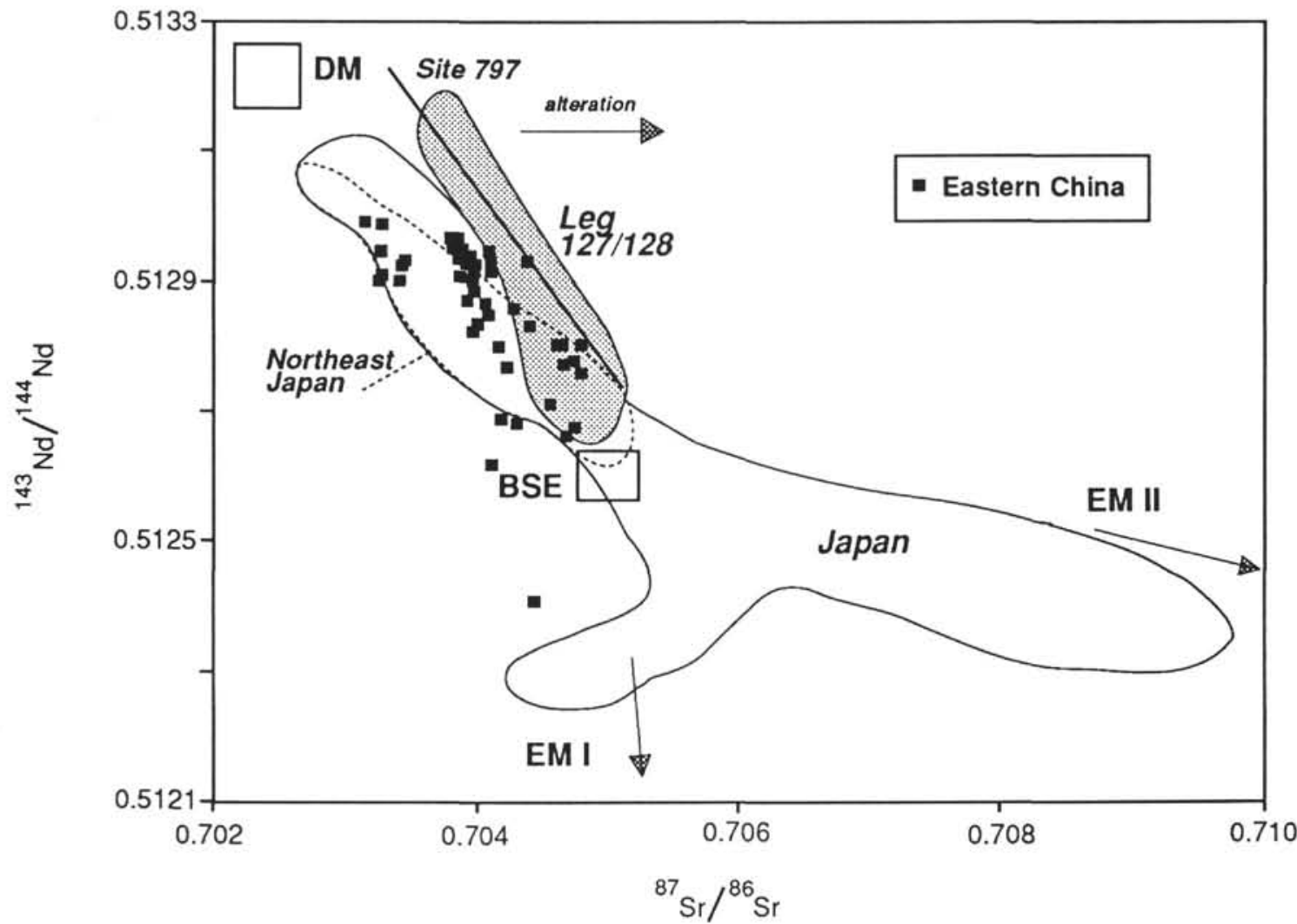

Figure 6. Nd-Sr isotope variation diagram, comparing fields for Japan-arc rocks, Cenozoic basalts from eastern China, and Leg 127/128 lavas (gray field). The best-fit regression line through Site 797 lavas is shown running through the Leg 127/128 field. BSE = bulk silicate earth, EM = enriched mantle I or II, from Zindler and Hart (1986). Note that it is difficult to infer the composition of the enriched component (BSE, EM I, EM II, or a mix) in Northeast Japan or Leg 127/128 lavas based solely on Sr and Nd isotope data, as both data fields plot within the mantle fan and do not show curvature toward either EM component. (Data sources: Peng et al., 1990; Song et al., 1990; Japan-arc data from Fig. 3)

produced by subcontinental lithospheric contamination of basaltic magmas in eastern China are opposite to those seen in Japanese arc lavas and Hole 797.

Alternatively, the subcontinental lithosphere beneath Japan may have developed subsequent to the initiation of arc volcanism during the Cretaceous. The subcontinental lithosphere would then be composed of the residue of partial melting events in the mantle wedge, and would be isotopically similar to the arc crust above it. It would then be impossible to distinguish the two as potential contaminants on purely isotopic grounds.

\section{Subducted Sediments}

The correlation of the three isotope systems puts some constraints on the composition of the two components in Sea of Japan backarc basalts. The correlation between ${ }^{206} \mathrm{~Pb} /{ }^{204} \mathrm{~Pb}$ ratios and $1 /[\mathrm{Pb}]$ is good, especially in Hole 797, supporting two-component mixing (Fig. 8A). The isotopic composition of a composite of Pacific pelagic sediments is a good candidate for the non-MORB component (Table 2). However, similar plots of ${ }^{87} \mathrm{Sr} /{ }^{86} \mathrm{Sr}$ vs. $1 /[\mathrm{Sr}]$ or ${ }^{143} \mathrm{Nd} /{ }^{144} \mathrm{Nd}$ vs. $1 /[\mathrm{Nd}]$ indicate that Japanese continental crust, including older granites and gneisses, is less likely to be this component, because their ${ }^{87} \mathrm{Sr} /{ }^{86} \mathrm{Sr}$ ratios are generally too high $(0.707-0.715)$ and ${ }^{143} \mathrm{Nd} /{ }^{144} \mathrm{Nd}$ ratios are too low (Nohda and Wasserburg, 1981; Arakawa, 1990a, 1990b).

Dredged lavas from the Yamato seamount chain (central Yamato Basin) have ${ }^{87} \mathrm{Sr} /{ }^{86} \mathrm{Sr}$ ratios between 0.70375 and 0.70388 , falling at the low end of the range observed in Hole 797 (Kaneoka et al., 1990). The seamounts appear to have formed after the major phase of opening of the Yamato Basin (Kaneoka et al., 1990) and are not part of a hotspot chain, so the most likely source of the seamount lavas was the mantle wedge. The low ${ }^{87} \mathrm{Sr} /{ }^{86} \mathrm{Sr}$ ratios suggest that either (a) the sedimentary component was volumetrically smaller in the source, perhaps because it was depleted during the major phase of spreading in the Sea of Japan, or (b) basaltic magmas were more effectively insulated from continental blocks trapped within the Sea of Japan such that crustal contamination was minimized, even though many of the Yamato Seamount lavas are quite evolved. Of course, ${ }^{87} \mathrm{Sr} /{ }^{86} \mathrm{Sr}$ ratios are still higher than MORB, so there is still an "enriched" component in these rocks.

If the enriched component is Pacific pelagic sediments, the proportions of the two components in the magmas can be estimated. The sediment and depleted MORB source compositions assumed for the mixing calculations are listed in Table 2 , and the results are plotted in Figure $8 \mathrm{~B}$. The percentage of sediments inferred to be in the mantle source varies from $0.5 \%$ to $2.0 \%$, which is greater than that estimated to be in Mariana arc magmas. Lavas from the Tonga arc (Oversby and Ewart, 1972) may have as much as $3 \%$ of a sedimentary component in the source, based on $\mathrm{Pb}$ isotopes. Note that the ${ }^{87} \mathrm{Sr} /{ }^{86} \mathrm{Sr}$ ratio assumed for the depleted source is much higher than that normally attributed to depleted MORB mantle. If the mantle wedge is indeed composed largely of depleted, MORB-like mantle, it may have already been enriched in ${ }^{87} \mathrm{Sr}$, perhaps as a result of incorporation of fluids driven from the subducting slab. The assumed $\mathrm{Sr}$ concentration in the sedimentary component is fairly low, only $240 \mathrm{ppm}$, compared to the Pacific authigenic weighted mean sediment (PAWMS) composition derived by Hole et al. (1984). However, PAWMS contains a high proportion of nannofossil ooze with a high $\mathrm{Sr}$ content, which is not representative of sediment being incorporated into the Japan 


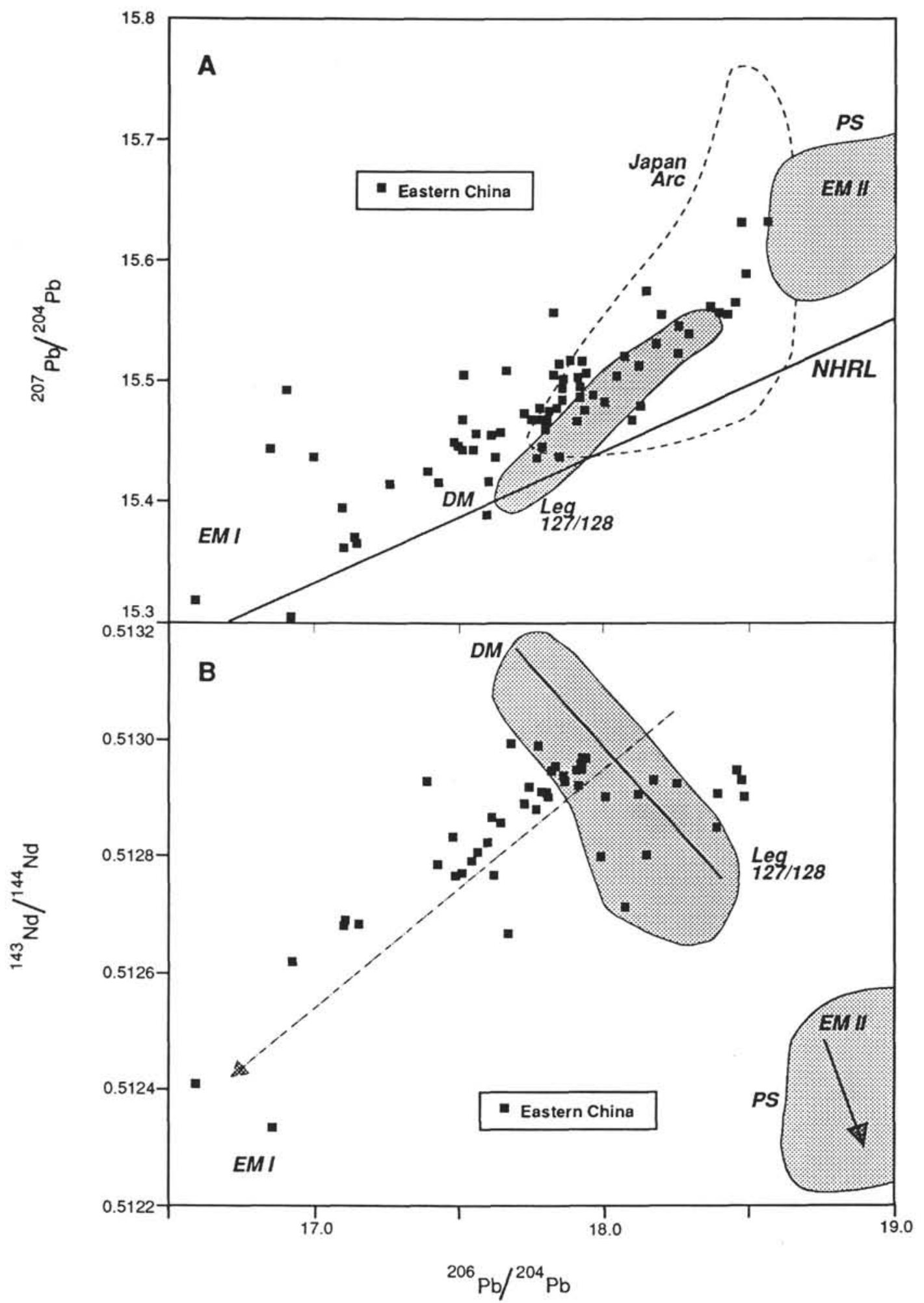

Figure 7. $\mathrm{Pb}-\mathrm{Pb}(\mathbf{A})$ and $\mathrm{Nd}-\mathrm{Pb}(\mathbf{B})$ isotope plots comparing Leg 127 backarc, Japanese arc, and eastern Chinese Cenozoic intraplate basalts. While the backarc and arc rocks lie on trends between depleted mantle and EM II (pelagic sediments), the Chinese lavas lie between an enriched MORB composition and EM I, which is interpreted to be subcontinental lithosphere (Zindler and Hart, 1986; Hawkesworth et al., 1990). (Data sources: Peng et al., 1990; Song et al., 1990; Japan arc data from Figs. 2 and 3 ) 

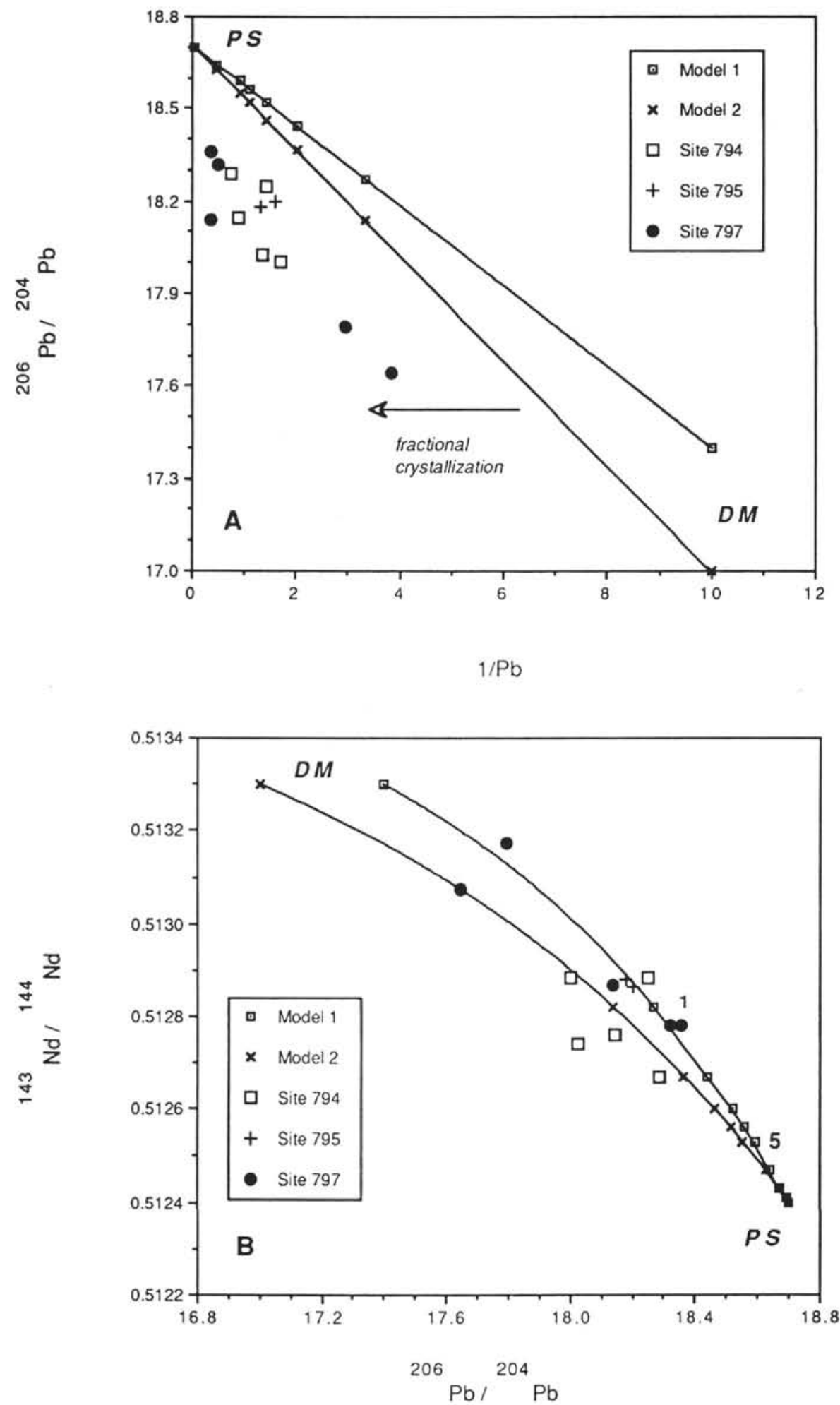

Figure 8. Two-component mixing plots between depleted mantle (DM) and pelagic sediments (PS) for Leg 127 basalts. A. The ${ }^{206} \mathrm{~Pb} /{ }^{204} \mathrm{~Pb}$ vs. $1 /[\mathrm{Pb}]$ plot suggests that the spread in isotopic composition is due to mixing between depleted mantle and pelagic sediments. Leg $127 / 128$ basalts fall to the right of the mixing line, possibly due to the effect of fractional crystallization. Mixing lines between DM and PS are shown, assuming Pb compositions listed in Table 2. Squares on the line are for $0 \%, 1 \%, 2 \%, 3 \%, 4 \%, 5 \%, 10 \%$, and $100 \%$ PS in the mix. B. ${ }^{143} \mathrm{Nd} /{ }^{144} \mathrm{Nd}$ vs. ${ }^{206} \mathrm{~Pb} /{ }^{204} \mathrm{~Pb}$ mixing curve for Leg $127 / 128$ basalts. Squares on the curves are shown at $0 \%, 1 \%$ (marked), $2 \%, 3 \%, 4 \%, 5 \%$ (marked), $10 \%, 20 \%, 60 \%$ and $100 \%$ PS in the mix. End-member compositions are defined in Table 2. The most enriched basalts have a maximum of $2 \%$ pelagic sediment component. 
Table 2. End-member compositions for mixing calculations.

\begin{tabular}{lcc}
\hline & Pelagic sediment & Depleted source \\
\hline${ }^{206} \mathrm{~Pb}{ }^{204} \mathrm{~Pb}$ & 18.70 & $17.40,17.00$ \\
${ }^{143} \mathrm{Nd} /{ }^{144} \mathrm{Nd}$ & 0.5124 & 0.5133 \\
${ }^{87} \mathrm{Sr}{ }^{86} \mathrm{Sr}$ & 0.7090 & 0.7035 \\
$\mathrm{~Pb}(\mathrm{ppm})$ & 20 & 0.1 \\
$\mathrm{Nd}(\mathrm{ppm})$ & 80 & 0.7 \\
$\mathrm{Sr}(\mathrm{ppm})$ & 240 & 12.0 \\
$\mathrm{La} / \mathrm{Sm}$ & 2.10 & 0.60 \\
$\mathrm{Sm}(\mathrm{ppm})$ & 18.1 & 0.25 \\
\end{tabular}

Note: Pacific pelagic sediment composite composition calculated from Shipboard Scientific Party (1975a, 1975b), Othman et al. (1989) and Hole et al. (1984). Depleted MORB source from Zindler and Hart (1986) except for ${ }^{87} \mathrm{Sr}{ }^{86} \mathrm{Sr}$ ratio. Two ${ }^{206} \mathrm{~Pb} /{ }^{204} \mathrm{~Pb}$ values for $\mathrm{DM}$ are used in mixing calculations: Model $1=17.4$, Model $2=17.0$.

sub-arc mantle (Shipboard Scientific Party, 1975a, 1975b). A lower Sr concentration in subducted sediments mixing with a MORB source produces a more realistic ${ }^{87} \mathrm{Sr} /{ }^{86} \mathrm{Sr}$ in the source of Mariana arc lavas than does the 1140- ppm Sr value for PAWMS (Hole et al., 1984).

Samples from the upper and lower complexes in Hole 797 have distinct major- element, trace-element, and isotopic compositions. However, all samples from Hole 797 lie on the highly correlated $\mathrm{Pb}-\mathrm{Pb}$ regression lines in Figure 2, with the samples from the lower complex plotting at the high ${ }^{206} \mathrm{~Pb} /{ }^{204} \mathrm{~Pb}$ end. This suggests that the two magmatic groups may be related by mixing, in that rocks in the lower complex contain a much larger contribution from the sedimentary component. Trace-element analysis shows that the lower complex lavas are enriched in LIL and light rare-earth elements compared to upper complex basalts (Tamaki, Pisciotto, Allan, et al., 1990; Allan and Gorton, this volume) and isotopic and incompatible element ratios are correlated (Fig. 5), as would be expected if they contained a larger sedimentary component. In what form the sedimentary component is introduced to the mantle wedge, as an aqueous fluid, a partial melt, or as bulk fragments of the sedimentary column, is an important question. The degree of alteration of these basalts, resulting in mobilization of critical LILE and Sr, makes it difficult to be quantitative when attempting to answer this question.

An aqueous fluid from sediments should have high LILE/REE, LILE/HFSE, $\mathrm{Sr} / \mathrm{Nd}$, and ${ }^{87} \mathrm{Sr}{ }^{86} \mathrm{Sr}$ ratios, as does an aqueous fluid derived from oceanic crust (e.g., Tatsumi et al., 1986). Ba/La ratios in basalts from the lower complex at Site 797 range between 15 and 17, higher than $\mathrm{Ba} / \mathrm{La}$ ratios in the upper complex and in MORB, but lower than $\mathrm{Ba} / \mathrm{La}$ in arc lavas interpreted to have predominantly an aqueous component added to their mantle source (e.g. Davidson, 1987).

We have attempted to model, to a first order only, the effect on rare-earth element patterns of sediment addition to depleted mantle (Fig. 9). A composite sediment composition was calculated for sediments currently being subducted at the Japan arc, using lithologic descriptions from DSDP Sites 303 and 304 (Shipboard Scientific Party, 1975a, 1975b) and modern sediment compositions from Othman et al. (1989), Toyoda et al. (1990), Stern and Ito (1983), and Hole et al. (1984). The uncontaminated mantle wedge composition was calculated assuming that the Unit 3 basalt was a $10 \%$ partial melt and that mantle/melt distribution coefficients for all elements were $<0.01$. If depleted mantle and composite sediment are mixed in the proportions $97: 3$, a $13 \%$ partial melt of this mixture produces a magma with a rare earth pattern similar to Unit 12 basalt. This partial melt has a prominent negative $\mathrm{Ce}$ anomaly that is not seen in Site 797 enriched basalts. The size of the $\mathrm{Ce}$ anomaly in the partial melt depends on the pelagic clay composition chosen when calculating the composite sediment bulk composition. In this case, a pelagic clay from just north of the Equator with a prominent $\mathrm{Ce}$ anomaly was chosen, but many pelagic clays in the northwestern Pacific have no Ce anomaly (Toyoda et al., 1990). Thus, to better quantify the geochemistry of a mixed mantle plus sediment source, we require better information on the geochemistry of sediments being subducted along the Japan arc. Source modeling is the subject of ongoing research (Cousens, Allan, and Gorton, unpubl. data).

Be isotopic studies support the proposition that pelagic sediments are present in the source of Japan arc lavas (Tera et al., 1986). Of nine arc volcanoes studies, three contain above-background concentrations of ${ }^{10} \mathrm{Be}$, whose source is presumed to be subducted Pliocene to Pleistocene-aged pelagic sediments. One of the three volcanoes is Oshima-Oshima, located $150 \mathrm{~km}$ behind the arc front, apparently in a backarc setting. It appears, therefore, that sediments may sometimes be subducted to great depth beneath and behind volcanic arcs (Tera et al., 1986), as we propose is occurring beneath the Sea of Japan.

\section{SUMMARY}

Basaltic rocks from the Sea of Japan, including basaltic sills and lava flows, span a large range in isotopic composition. The isotopic characteristics of these backarc lavas are very similar to those of Neogene and Quaternary arc volcanics from northern Japan, and are quite different from other back-arc basin lavas from the northwestern Pacific. The lavas form correlated arrays on isotope-isotope and isotope-incompatible element ratio plots, and we propose that the major process that controls the isotopic composition of these rocks is mixing of subducted pelagic sediments with depleted MORB mantle in the mantle wedge. The proportion of the sedimentary component in the source varies from $0.5 \%$ to $2.5 \%$.

\section{ACKNOWLEDGMENTS}

Many thanks to George Tilton for access to the excellent mass spectrometer facilities at University of California, Santa Barbara, and to Michael Ort for performing Nd analyses of Hole 794C basalts. BLC is grateful to John Ludden for financial assistance while attending the ODP post-cruise meeting and for his enthusiastic support of the project. Thorough reviews by Don Francis and John Ludden dramatically improved the manuscript. Thoughtful reviews by Jon Davidson and Michael Perfit are appreciated. Thanks to Caroline Choquette and Kelly Douglas for help in preparing the initial manuscript. This project has been supported by a USSAC/ODP grant to JFA, BLC, and M. Gorton, and an NSERC of Canada CSP grant to BLC.

\section{REFERENCES}

Arakawa, Y., 1990a. Strontium isotopic compositions of Mesozoic granitic rocks in the Hida Belt, central Japan: diversities of magma sources and the processes of magma evolution in a continental margin area. Lithos, 24:261-273.

, $1990 \mathrm{~b}$. Two types of granitic intrusions in the Hida Belt, Japan: $\mathrm{Sr}$ isotopic and chemical characteristics of the Mesozoic Funatsu granitic rocks. Chem. Geol., 85:101-117.

Arculus, R. J., and Powell, R., 1986. Source component mixing in the regions of arc magma generation. J. Geophys. Res., 91:5913-5926.

Cousens, B. L., Spera, F. J., and Tilton, G. R., 1990. Isotopic patterns in silicic ignimbrites and lava flows of the Mogan and lower Fataga Formations, Gran Canaria, Canary Islands: temporal changes in mantle source composition. Earth Planet. Sci. Lett., 96:319-335.

Davidson, J. P., 1987. Crustal contamination versus subduction zone enrichment: examples from the Lesser Antilles and implications for mantle source compositions of island arc volcanic rocks. Geochim. Cosmochim. Acta, 51:2185-2198.

Defant, M. J., Jacques, D., Maury, R. C., de Boer, J., and Joron, J.-L., 1989. Geochemistry and tectonic setting of the Luzon arc, Philippines. Geol. Soc. Am. Bull., 101:663-672.

Eggler, D. H., 1987. Solubility of major and trace elements in mantle metasomatic fluids: experimental constraints. In Menzies, M., and Hawkesworth, C. J. (Eds.), Mantle Metasomatism: London (Academic Press), 21-41. 
Ellam, R. M., and Hawkesworth, C. J., 1988. Elemental and isotopic variations in subduction related basalts: evidence for a three component model. Contrib. Mineral. Petrol., 98:72-80.

Ewart, A., and Hawkesworth, C. J., 1987. The Pleistocene-Recent Tonga-Kermadec arc lavas: interpretation of new isotopic and rare earth data in terms of a depleted mantle source model. J. Petrol., 28:495-530.

Gill, J. B., 1981. Orogenic Andesites and Plate Tectonics: Berlin (Springer-Verlag).

Hart, S. R., 1984. A large-scale isotope anomaly in the Southern Hemisphere. Nature, 309:753-756.

Hawkesworth, C. J., Kempton, P. D., Rogers, N. W., Ellam, R. M., and van Calsteren, P. W., 1990. Continental mantle lithosphere, and shallow enrichment processes in the Earth's mantle. Earth Planet. Sci. Lett., 96:256-268.

Hawkins, J. W., and Melchior, J. T., 1985. Petrology of Mariana Trough and Lau Basin basalts. J. Geophys. Res., 90:11431-11468.

Hochstaeder, A. G., Gill, J. B., and Morris, J. D., 1990. Volcanism in the Sumisu Rift, II. Subduction and non-subduction related components. Earth Planet. Sci. Lett., 100:195-209.

Hole, M. J., Saunders, A. D., Marriner, G. F., Tarney, J., 1984. Subduction of pelagic sediments: implications for the origin of Ce-anomalous basalts from the Marianas Islands. J. Geol. Soc, London, 141:453-472.

Ingle, J. C., Jr., Suyehiro, K., von Breymann, M. T., et al., 1990. Proc. ODP, Init. Repts, 128: College Station, TX (Ocean Drilling Program).

Ishizaka, K., and Carlson, R. W., 1983. Nd-Sr systematics of the Setouchi volcanic rocks, southwest Japan: a clue to the origin of orogenic andesite. Earth Planet. Sci. Lett., 64:327-340.

Kaneoka, I., 1990. Radiometric age and $\mathrm{Sr}$ isotope characteristics of volcanic rocks from the Japan Sea floor. Geochem. J., 24:7-19.

Kaneoka, I., Notsu, K., Takigami, Y., Fujioka, K., and Sakai, H., 1990. Constraints on the evolution of the Japan Sea based on ${ }^{40} \mathrm{Ar} /{ }^{39} \mathrm{Ar}$ ages and $\mathrm{Sr}$ isotopic ratios for volcanic rocks of the Yamato Seamount Chain in the Japan Sea. Earth Planet. Sci. Lett., 97:211-225.

Ludden, J. N., and Thompson, G., 1979. An evaluation of the behavior of the rare earth elements during the weathering of sea floor basalt. Earth Planet. Sci. Lett., 43:85-92.

Meijer, A., 1975. $\mathrm{Pb}$ and $\mathrm{Sr}$ isotopic studies of igneous rocks cored during Leg 31 of the Deep Sea Drilling Project, In Karig, D. E., Ingle, J. C., et al., Init. Repts. DSDP, 31: Washington, D.C. (U.S. Govt. Printing Office), 601-606.

$\longrightarrow, 1976 . \mathrm{Pb}$ and $\mathrm{Sr}$ isotopic evidence bearing on the origin of volcanic rocks from the Mariana island arc system. Geol. Soc. Am. Bull., 87:1358-1369.

Menzies, M. A., 1989. Cratonic, circumcratonic, and oceanic mantle domains beneath the western United States. J. Geophys. Res., 94:7899-7915.

Morris, P. A., and Kagami, H., 1989. Nd and Sr isotope systematics of Miocene to Holocene volcanic rocks from Southwest Japan: volcanism since the opening of the Sea of Japan. Earth Planet. Sci. Lett., 92:335-346.

Nakamura, E., Campbell, I. H., and Sun, S.-S., 1985. The influence of subduction processes on the geochemistry of Japanese alkaline basalts. Nature, 316:55-58.

Nohda, S., and Wasserberg, G. J., 1981. Nd and Sr isotopic study of volcanic rocks from Japan. Earth Planet. Sci. Lett., 52:264-276.

, 1986. Trends of $\mathrm{Sr}$ and $\mathrm{Nd}$ isotopes through time near the Japan Sea in northeastern Japan. Earth Planet. Sci. Lett., 78:157-167.

Nohda, S., Tatsumi, Y., Otofuji, Y.-I., Matsuda, T., and Ishizaka, K., 1988. Asthenospheric injection and back-arc opening: isotopic evidence from northeastern Japan. Chem. Geol., 68:317-327.

Notsu, K., 1983. Strontium isotope composition in volcanic rocks from the northeast Japan arc. J. Volcanol. Geotherm. Res., 18:531-548.

Othman, D. B., White, W. M., and Patchett, J., 1989. The geochemistry of marine sediments, island arc genesis, and crust-mantle recycling. Earth Planet. Sci. Lett., 94:1-21.

Oversby, V. M., and Ewart, A., 1972. Lead isotopic compositions of TongaKermadec volcanics and their petrogenetic significance. Contrib. Mineral. Petrol., 37:181-210.

Peng, Z. C., Zartman, R. E., Futa, K., and Chen, D. G., 1986. Pb-, Sr-, and Nd-isotope systematics and the chemical characteristics of Cenozoic basalts, eastern China. Chem. Geol. (Iso. Geosci. Sec.), 59:3-33.

Perfit, M. R., Gust, D. A., Bence, A. E., Arculus, R. J., and Taylor, S. R., 1980. Chemical characteristics of island-arc basalts: implications for mantle sources. Chem. Geol., 30:227-256.

Shipboard Scientific Party, 1975a. Site 303: Japanese magnetic lineations. In Larson, R. L., Moberly, R., et al., Init. Repts. DSDP, 32: Washington (U.S. Govt. Printing Office), 17-43. 1975b. Site 304: Japanese magnetic lineations. In Larson, R. L., Moberly, R., et al., Init. Repts. DSDP, 32: Washington (U.S. Govt. Printing Office), 45-73.

Song, Y., Frey, F. A., and Zhi, X., 1990. Isotopic characteristics of Hannuoba basalts, eastern China: implications for their petrogenesis and the composition of the subcontinental mantle. Chem. Geol., 85:35-52.

Stern, R. J., and Ito, E., 1983. Trace element and isotopic constraints on the source of magmas in the Active volcano and Mariana island arcs, Western Pacific. J. Volcanol. Geotherm. Res., 18:461-482.

Stern, R. J., Lin, P.-N., Morris, J. D., Jackson, M. C., Fryer, P., Bloomer, S. H., and Ito, E., 1990. Enriched back-arc basin basalts from the northern Mariana Trough: implications for the magmatic evolution of back-arc basins. Earth Planet. Sci. Lett., 100:210-225.

Tamaki, K., 1988. Geological structure of the Japan Sea and its tectonic implications. Chishitsu Chosasho Geppo, 39:269-365.

Tamaki, K., Pisciotto, K., Allan, J., et al., 1990. Proc. ODP, Init. Repts., 127: College Station, TX (Ocean Drilling Program).

Tatsumi, Y., Hamilton, D. L., and Nesbitt, R. W., 1986. Chemical characteristics of fluid phase released from a subducted lithosphere and the origin of arc magmas: evidence from high pressure experiments and natural rocks. J. Volcanol. Geotherm. Res., 29:293-309.

Tatsumi, Y., Nohda, S., and Ishizaka, K., 1988. Secular variation of magma source compositions beneath the NE Japan arc. Chem. Geol., 68:309-316.

Tatsumoto, M., 1969. Lead isotopes in volcanic rocks and possible ocean floor thrusting beneath island arcs. Earth Planet. Sci. Lett., 6:369-376.

Tera, F., Brown, L., Morris, J., and Sacks, I. S., 1986. Sediment incorporation in island arc magmas: inferences from ${ }^{10} \mathrm{Be}$. Geochim. Cosmochim. Acta, 50:535-550.

Terakado, Y., Shimizu, H., and Masuda, A., 1988. Nd and Sr isotopic variations in acidic rocks formed under a peculiar tectonic environment in Miocene Southwest Japan. Contrib. Mineral. Petrol., 99:1-10.

Todt, W., Cliff, R. A., Hanser, A., and Hofmann, A. W., $1984 .{ }^{202} \mathrm{~Pb}-{ }^{205} \mathrm{~Pb}$ spike for $\mathrm{Pb}$ isotopic analysis. Terra Cognita, 4:209.

Toyoda, K., Nakamura, Y., and Masuda, A., 1990. Rare earth elements in Pacific pelagic sediments. Geochim. Cosmochim. Acta, 54:1093-1103.

Ueno, N., Kaneoka, I., and Ozima, M., 1974. Isotopic ages and strontium isotopic ratios of submarine rocks in the Japan Sea. Geochem. J., 8:157-164.

Volpe, A. M., Macdougall, J. D., Lugmair, G. W., Hawkins, J. W., and Lonsdale, P., 1990. Fine-scale isotopic variation in Mariana Trough basalts: evidence for heterogeneity and a recycled component in backarc basin basalts. Earth Planet. Sci. Lett., 100:251-264.

White, W. M., and Patchett, J., 1984. Hf-Nd-Sr isotopes and incompatible element abundances in island arcs: implications for magma origins and crust-mantle evolution. Earth Planet. Sci. Lett., 67:167-185.

Whitford, D. J., and Jezek, P. A., 1979. Origin of late Cenozoic lavas from the Banda Arc, Indonesia: trace element and $\mathrm{Sr}$ isotope evidence. Contrib. Mineral. Petrol., 68:141-150.

Woodhead, J. D., and Fraser, D. G., 1985. Pb, $\mathrm{Sr}$, and ${ }^{10} \mathrm{Be}$ isotopic studies of volcanic rocks from the northern Marianas Islands: implications for magma genesis and crustal recycling in the Western Pacific. Geochim. Cosmochim. Acta, 49:1925-1930.

Woodhead, J. D., Harmon, R. S., and Fraser, D. G., 1987. O, S, Sr, and Pb isotopic variations in volcanic rocks from the Northern Mariana Islands: implications for crustal recycling in intra-oceanic arcs. Earth Planet. Sci. Lett., 83:39-52.

Zhi, X., Song, Y., Frey, F. A., Feng, J., and Zhai, M., 1990. Geochemistry of the Hannuoba basalts, eastern China: constraints on the origin of continental alkalic and tholeiitic basalt. Chem. Geol., 88:1-33.

Zhou, X., and Armstrong, R. L., 1982. Cenozoic volcanic rocks of eastern China - secular and geographic trends in chemistry and strontium isotopic composition. Earth Planet. Sci. Lett., 58:301-329.

Zindler, A., and Hart, S. R., 1986. Chemical geodynamics. Annu. Rev. Earth Planet. Sci., 14:493-571.

Date of initial receipt: 19 March 1991

Date of acceptance: 25 October 1991

Ms 127/128B-199 

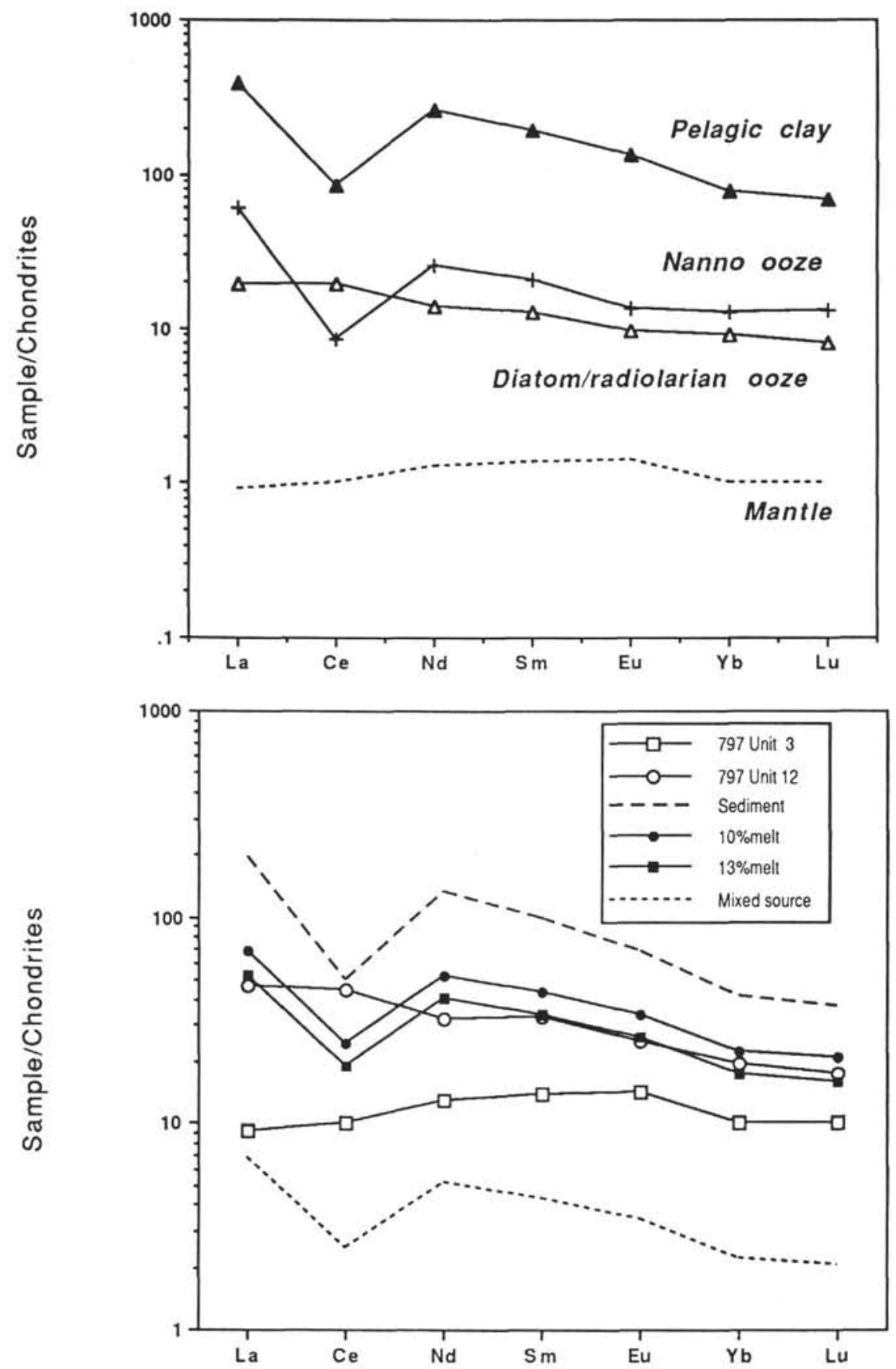

Figure 9. REE mixing model showing the effect of mixing of pelagic sediment into depleted mantle. The depleted mantle pattern is calculated from the composition of Unit 3 depleted tholeiite, and the sediment is a composite of modern Pacific sediments whose REE patterns are shown in the upper part of the diagram. A 10\%-13\% partial melt of a mixed ( $97 \%$ mantle, $3 \%$ sediment) source yields an REE pattern similar to enriched tholeiite from Unit 13. Data sources are listed in the text. 